\title{
Experimental Gasification of Biomass in an Updraft Gasifier with External Recirculation of Pyrolysis Gases
}

\author{
Adi Surjosatyo, Fajri Vidian, and Yulianto Sulistyo Nugroho \\ Department of Mechanical Engineering, Faculty of Engineering, Universitas Indonesia, UI Campus, Depok 16242, Indonesia \\ Correspondence should be addressed to Adi Surjosatyo; adisur@eng.ui.ac.id
}

Received 30 September 2013; Accepted 5 December 2013; Published 23 January 2014

Academic Editor: Constantine D. Rakopoulos

Copyright ( 2014 Adi Surjosatyo et al. This is an open access article distributed under the Creative Commons Attribution License, which permits unrestricted use, distribution, and reproduction in any medium, provided the original work is properly cited.

\begin{abstract}
The updraft gasifier is a simple type of reactor for the gasification of biomass that is easy to operate and has high conversion efficiency, although it produces high levels of tar. This study attempts to observe the performance of a modified updraft gasifier. A modified updraft gasifier that recirculates the pyrolysis gases from drying zone back to the combustion zone and gas outlet at reduction zone was used. In this study, the level of pyrolysis gases that returned to the combustion zone was varied, and as well as measurements of gas composition, lower heating value and tar content. The results showed that an increase in the amount of pyrolysis gases that returned to the combustion zone resulted in a decrease in the amount of tar produced. An increase in the amount of recirculated gases tended to increase the concentrations of $\mathrm{H}_{2}$ and $\mathrm{CH}_{4}$ and reduce the concentration of $\mathrm{CO}$ with the primary (gasification) air flow held constant. Increasing the primary air flow tended to increase the amount of $\mathrm{CO}$ and decrease the amount of $\mathrm{H}_{2}$. The maximum of lower heating value was $4.9 \mathrm{MJ} / \mathrm{m}^{3}$.
\end{abstract}

\section{Introduction}

The development of industry around the world has resulted in an enormous demand for energy that will continue to rise. However, the supply and the availability of energy from fossil fuels will decrease. Biomass is an environmentally sustainable alternative energy source that is widely available around the world [1]. Using biomass sources such as wood, rice husks, and bagasse, which have the highest energy content, together with the highest-efficiency conversion methods would add a significant amount of energy. The use of biomass for biofuels has reached approximately $9-14 \%$ of the total of energy demand worldwide [2].

Gasification is an ecoefficient and sustainable thermochemical conversion method [3] that creates low levels of pollution [4].

Various forms of gasifiers have been developed to meet criteria of being easy to operate, being highly efficient, and producing relatively low amounts of tar. The two most popular types of fixed-bed reactors used are the updraft gasifier and the downdraft gasifier. The updraft gasifier is easy to operate and has quite high conversion efficiency, but this type produces high levels of tar, as high as $0.2 \mathrm{~kg} / \mathrm{m}^{3}$ [5], because the pyrolysis gases containing high levels of tar are extracted directly from the reactor. This increases the load on the gas cleaning system and the level of carcinogenic waste produced [1].

Modifying the reactor is one common method used to reduce the level of tar produced from the gasification. The gasifier could be modified with recirculaton of pyrolysis gas and modification of gas outlet [6].

This study presents a study of a modified updraft gasifier with recirculaton of the pyrolysis gases back to the combustion zone and the gas outlet at the reduction zone. The effects on combustible gas composition, the LHV, and the tar content of the producer gas were investigated.

\section{Material and Methods}

The fuel used was woody biomass that was cut into pieces of $0.03 \mathrm{~m}$ wide and $0.03 \mathrm{~m}$ long and had a moisture content of $10.24 \%$. The proximate and ultimate analyses of this fuel are shown in Table 1. 


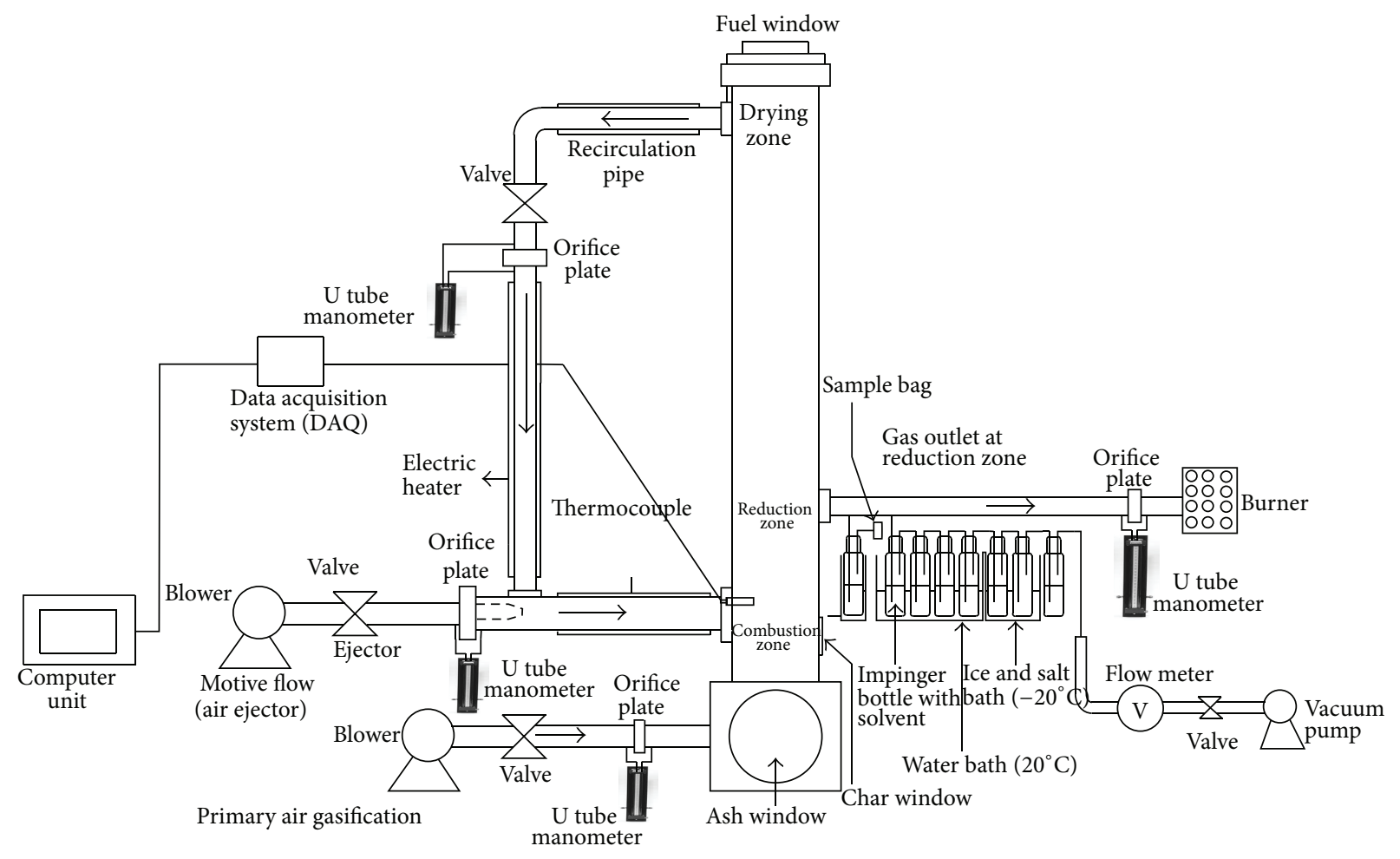

FIgURE 1: Experimental Setup.

Table 1: Proximate and ultimate analyses [7].

\begin{tabular}{lcc}
\hline \multicolumn{3}{c}{ Proximate and ultimate analyses } \\
& Unit & Value \\
\hline Proximate analysis & \\
Moisture (adb) & $\%$ & 10.24 \\
Ash & $\%$ & 2.71 \\
Volatile & $\%$ & 71.80 \\
Fixed carbon & $\%$ & 15.25 \\
Ultimate analysis & $\%$ & \\
Carbon & $\%$ & 43.33 \\
Hydrogen & $\%$ & 5.11 \\
Nitrogen & & Not detected \\
Sulfur & $\mathrm{Not}$ detected \\
Oxygen & $\mathrm{kJ} / \mathrm{kg}$ & 38.61 \\
Calorific value & $\mathrm{kg} / \mathrm{m}^{3}$ & 17025 \\
Density & & 640 \\
\hline
\end{tabular}

The gasification process included a gasification reactor with a diameter of $0.22 \mathrm{~m}$ and a length of $0.63 \mathrm{~m}$ and constructed of stainless steel (SUS 304 [7]), as shown in Figure 1. Type-K thermocouples were placed at the bottom of the reactor wall to measure the temperature inside the combustion zone reactor. Two air supplies were used in this process: the primary air and the motive flow (ejector air). The primary air for combustion was supplied using a blower and the motive flow for driving pyrolysis gas was supplied by a ring blower. The flow rates of the primary air, the motive flow, and the recirculated gas were measured using orifice plate flow meters. The producer gas outlet from the reactor was at a height of $0.13 \mathrm{~m}$ above the grate (at reduction zone). Recirculation pipes with a diameter of $0.05 \mathrm{~m}$ running from the top (drying zone) to the bottom of the reactor (the combustion zone) were constructed from stainless steel and equipped with control valves to manage the recirculation flow. The pyrolysis gas was driven to the combustion zone by the motive flow (air ejector) in the recirculation pipes. The recirculation pipes were heated using an electric heater to a temperature of $623^{\circ} \mathrm{K}$ to prevent tar condensation [8]. The tar content in the producer gases was measured using six impinger bottles, five of which were filled with a solvent (isopropanol) and one which was empty, as in $[7,9,10]$. Approximately $0.00005 \mathrm{~m}^{3}(50 \mathrm{~mL})$ of solvent was used to fill each of the five bottles. Subsequently, the solvent containing the tar was vaporised at a temperature of $380^{\circ} \mathrm{K}[11,12]$. The tar that was not vaporised was measured to determine the mass of the $\operatorname{tar}\left(\mathrm{kg} / \mathrm{m}^{3}\right)$. The gas composition was taken using sample tight bags, then it was analyzed using gas chromatography with thermal conductivity detector (TCD).

The ejector was a constant-mixing-area type, and the convergence nozzle had the following dimensions: the diameters of the inlet and outlet air were $0.025 \mathrm{~m}$ and $0.0075 \mathrm{~m}$, respectively, and the nozzle exit position (NXP) was $-0.03 \mathrm{~m}$ before the entrance of mixing chamber [13]. 


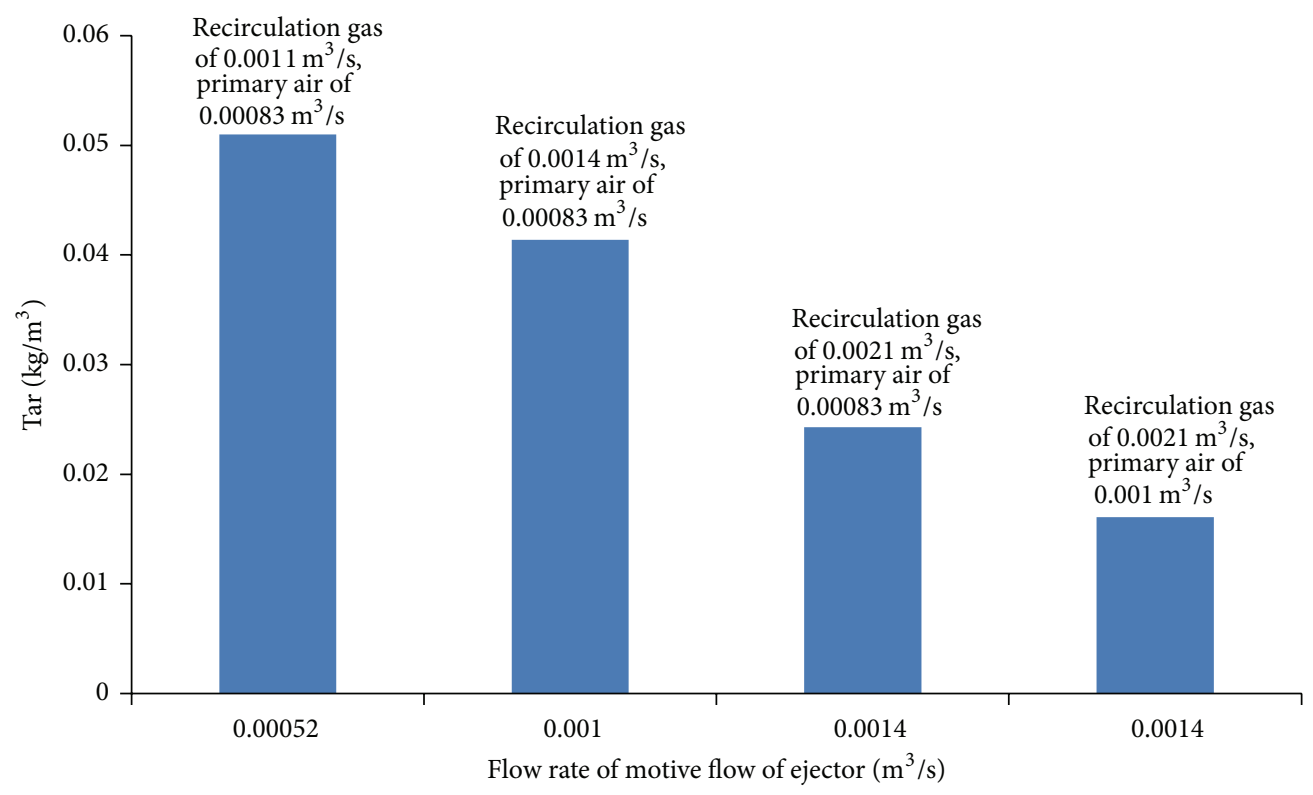

FIGURE 2: Tar content versus motive flow ejector.

The lower heating value (LHV) of producer gas was calculated using calorific value of moles fraction of combustible gas $\left(\mathrm{CO}, \mathrm{H}_{2}, \mathrm{CH}_{4}\right)[14]$ :

$$
\operatorname{LHV}\left(\mathrm{kJ} / \mathrm{m}^{3}\right)=y_{\mathrm{CO}} \cdot 12621+y_{\mathrm{H}_{2}} \cdot 10779+y_{\mathrm{CH}_{4}} \cdot 35874,
$$

where $y_{i}$ values are volume fractions of main combustible gas in the producer gas.

The mass of tar was calculated based on differences of mass impinger bottle containing tar and empty impinger bottle:

$$
\text { Gravimetric tar }\left(\mathrm{kg} / \mathrm{m}^{3}\right)=\frac{\text { mass of bottle containing } \operatorname{tar}(\mathrm{kg})-\text { mass of empty bottle }(\mathrm{kg})}{\text { flow rate of tar sampling }\left(\mathrm{m}^{3} / \mathrm{s}\right) \times \text { time of tar sampling }(\mathrm{s})} \text {. }
$$

To begin the tests, approximately $0.5 \mathrm{~kg}$ of fuel was placed in the reactor and burned until the temperature reached the maximum of $473^{\circ} \mathrm{K}$. Next, approximately $6 \mathrm{~kg}$ of additional fuel was placed into the reactor until the reactor was nearly full. After 900 seconds of operation, the combustible gases were obtained. The primary air gasification (primary air flow) was varied of $0.00083 \mathrm{~m}^{3} / \mathrm{s}$ and $0.001 \mathrm{~m}^{3} / \mathrm{s}$. The motive flow of ejector (air ejector) was varied of $0.00052 \mathrm{~m}^{3} / \mathrm{s}, 0.001 \mathrm{~m}^{3} / \mathrm{s}$, and $0.0014 \mathrm{~m}^{3} / \mathrm{s}$. The experiment was carried out at constant primary air gasification and the air ejector was increased, then the air ejector was held constant and the primary air was increased. The gas composition was taken for the sampling at the temperature of combustion zone was stable. Tar samples were taken at the temperature of the combustion zone was stable, while the flow rate of gas sampling was set at $3.3 \times$ $10^{-5} \mathrm{~m}^{3} / \mathrm{s}$ and the sampling time was about 240 seconds for each experiment.

\section{Results and Discussion}

3.1. Tar Content. Figure 2 shows the effect of the flow rate of the recirculated pyrolysis gases on the amount of tar produced. At recirculated pyrolysis gas flow rates of 0.0011 , 0.0014 , and $0.0021 \mathrm{~m}^{3} / \mathrm{s}$, generated with ejector motive flow rates of $0.00052 \mathrm{~m}^{3} / \mathrm{s}, 0.001 \mathrm{~m}^{3} / \mathrm{s}$, and $0.0014 \mathrm{~m}^{3} / \mathrm{s}$, respectively, the resulting tar concentrations were approximately $0.051,0.0414$, and $0.0243 \mathrm{~kg} / \mathrm{m}^{3}$ respectively, indicating a reduction in the tar content. At a motive flow rate of $0.0014 \mathrm{~m}^{3} / \mathrm{s}$, the primary air flow rate was increased to $0.001 \mathrm{~m}^{3} / \mathrm{s}$, and the tar concentration was reduced to $0.0161 \mathrm{~kg} / \mathrm{m}^{3}$. This reduction in the amount of tar resulted from the cracking (reactions (8)) and reforming (reactions (9) and reactions (10)) process of tar into combustible gases $\left(\mathrm{H}_{2}\right.$ and $\left.\mathrm{CO}\right)$ at a temperature of approximately $923-973^{\circ} \mathrm{K}$ $[15,16]$. Figure 5 shows the temperature in the combustion zone for every operating condition above $1073^{\circ} \mathrm{K}$ for which cracking and reforming tar is possible. The cracking and reforming of the tar will contribute more to $\mathrm{H}_{2}$ (reactions (8), and (9)) production when the primary air flow rate is constant and the motive flow of the ejector is varied. When the primary gasification was increased, there was a tendency towards an increased contribution of tar reforming to $\mathrm{CO}$ production (reactions (10)) as an effect of the increase 


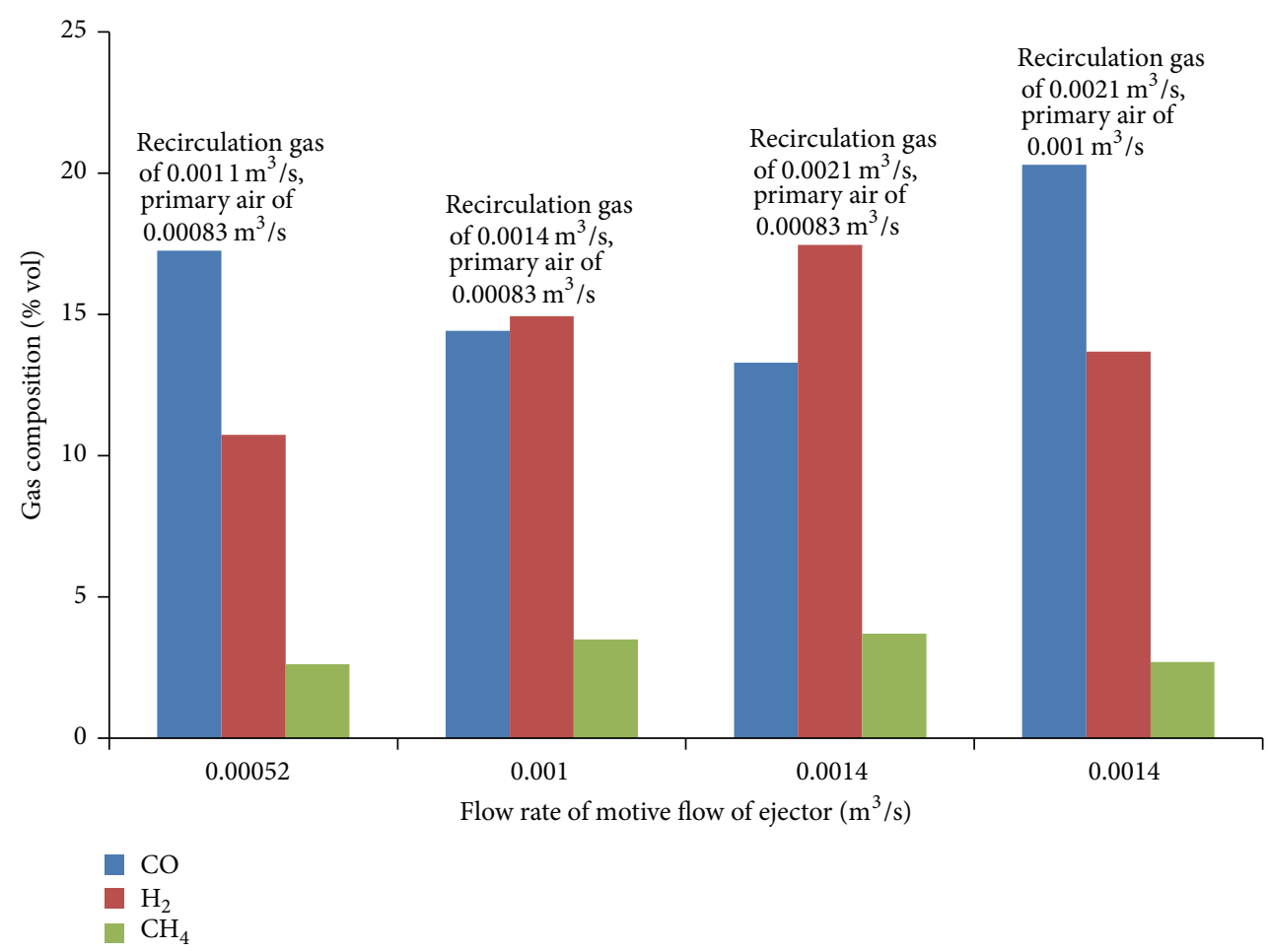

FIGURE 3: Gas concentration versus motive flow ejector.

of combustion reaction (reaction (7)), as shown in Figure 3.

3.2. Gas Compositionzz. Figure 3 shows the concentrations of the gases resulting from the recirculation of the pyrolysis gases back to the combustion zone.

Increasing the recirculation of the pyrolysis gas from $0.0011 \mathrm{~m}^{3} / \mathrm{s}$ to a maximum of $0.0021 \mathrm{~m}^{3} / \mathrm{s}$ at a constant primary air flow rate of $0.00083 \mathrm{~m}^{3} / \mathrm{s}$ caused the concentration of $\mathrm{H}_{2}$ to increase from $10.74 \%$ to $17.46 \%$ and the concentration of $\mathrm{CH}_{4}$ to increase from $2.62 \%$ to $3.7 \%$; however, the concentration of CO decreased from $17.25 \%$ to $13.29 \%$. This upward trend was caused by the water vapour $\left(\mathrm{H}_{2} \mathrm{O}\right)$ present in pyrolysis gases reacting with the $\mathrm{C}$ and the $\mathrm{CO}$ at high temperatures (above $1073^{\circ} \mathrm{K}$ ) to produce $\mathrm{H}_{2}$ (reactions (3)) and (reactions (4)). According to Kumar et al. (2009), the water gas reaction should increase at temperatures between $1023^{\circ} \mathrm{K}$ and $1073^{\circ} \mathrm{K}$ [17]. The reaction of tar cracking (reactions (8)) and steam reforming of the tar (reactions (9)) at temperatures of approximately $923^{\circ} \mathrm{K}$ to $973^{\circ} \mathrm{K}[15,16]$ would contribute to an increase in $\mathrm{H}_{2}$. The decrease in the $\mathrm{CO}$ concentration due to a decrease in the dominance of the boudouard reaction (reactions (5)) caused a temperature reduction. The increase in the $\mathrm{CH}_{4}$ level was caused by an increase in the methanisation reaction (reactions (6)) because the pressure increased in the gasifier as an effect of the pressure of the ejector. According to Kaupp and Gross (1981) [18] and Donaj et al. (2011) [19], an increase in the pressure inside the reactor increases the concentration of $\mathrm{CH}_{4}$.

When the recirculation flow rate was at a maximum of $0.0021 \mathrm{~m}^{3} / \mathrm{s}$ and the primary air flow rate was increased to
$0.001 \mathrm{~m}^{3} / \mathrm{s}$, the concentration of CO increased from $13.29 \%$ to $20 \%$, but the concentrations of $\mathrm{H}_{2}$ and $\mathrm{CH}_{4}$ decreased from $17.46 \%$ to $13.68 \%$ and from $3.7 \%$ to $2.69 \%$, respectively. Because the increase in the primary air flow rate increases the combustion reaction (reactions (7)) and the temperature inside the reactor, this contributed to a reduction in the reaction that produces $\mathrm{H}_{2}$ (reaction (3)) and (reaction (4)) and an increase in the boudauard reaction (reaction (5)) [20] and dry reforming of the tar (reaction (10)). The decrease in $\mathrm{H}_{2}$ contributed to a reduction in $\mathrm{CH}_{4}$ (reaction (6)) The increased temperature inside the reactor (Figure 5) contributed to the decrease in the $\mathrm{CH}_{4}$ concentration $[20,21]$.

Consider gasification, tar cracking, and tar reforming reaction as follows:

$$
\begin{gathered}
\mathrm{C}+\mathrm{H}_{2} \mathrm{O} \longrightarrow \mathrm{CO}+\mathrm{H}_{2} \\
\mathrm{CO}+\mathrm{H}_{2} \mathrm{O} \longrightarrow \mathrm{CO}_{2}+\mathrm{H}_{2} \\
\mathrm{C}+\mathrm{CO}_{2} \longrightarrow 2 \mathrm{CO} \\
\mathrm{C}+\mathrm{H}_{2} \longrightarrow \mathrm{CH}_{4} \\
\mathrm{C}+\mathrm{O}_{2} \longrightarrow \mathrm{CO}_{2} \\
\mathrm{C}_{x} \mathrm{H}_{y} \longrightarrow n \mathrm{C}+\left(\frac{x}{2}\right) \mathrm{H}_{2} \\
\mathrm{C}_{x} \mathrm{H}_{y}+m \mathrm{H}_{2} \mathrm{O} \longrightarrow n \mathrm{CO}+\left(\frac{m+y}{2}\right) \mathrm{H}_{2} \\
\mathrm{C}_{x} \mathrm{H}_{y}+m \mathrm{CO}_{2} \longrightarrow\left(\frac{x}{2}\right) \mathrm{H}_{2}+2 m \mathrm{CO}
\end{gathered}
$$




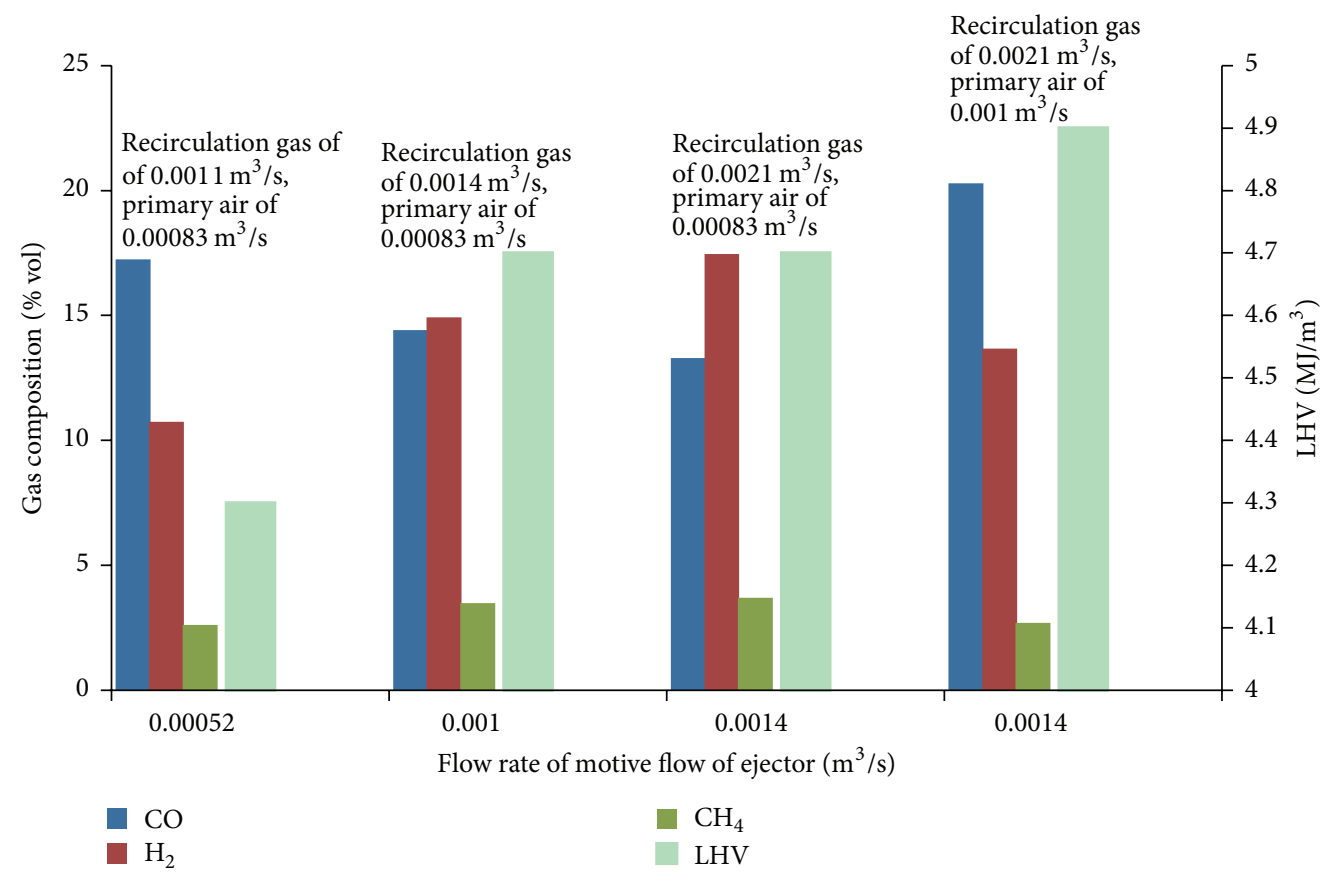

FIGURE 4: Lower heating values of gases versus motive flow ejector.

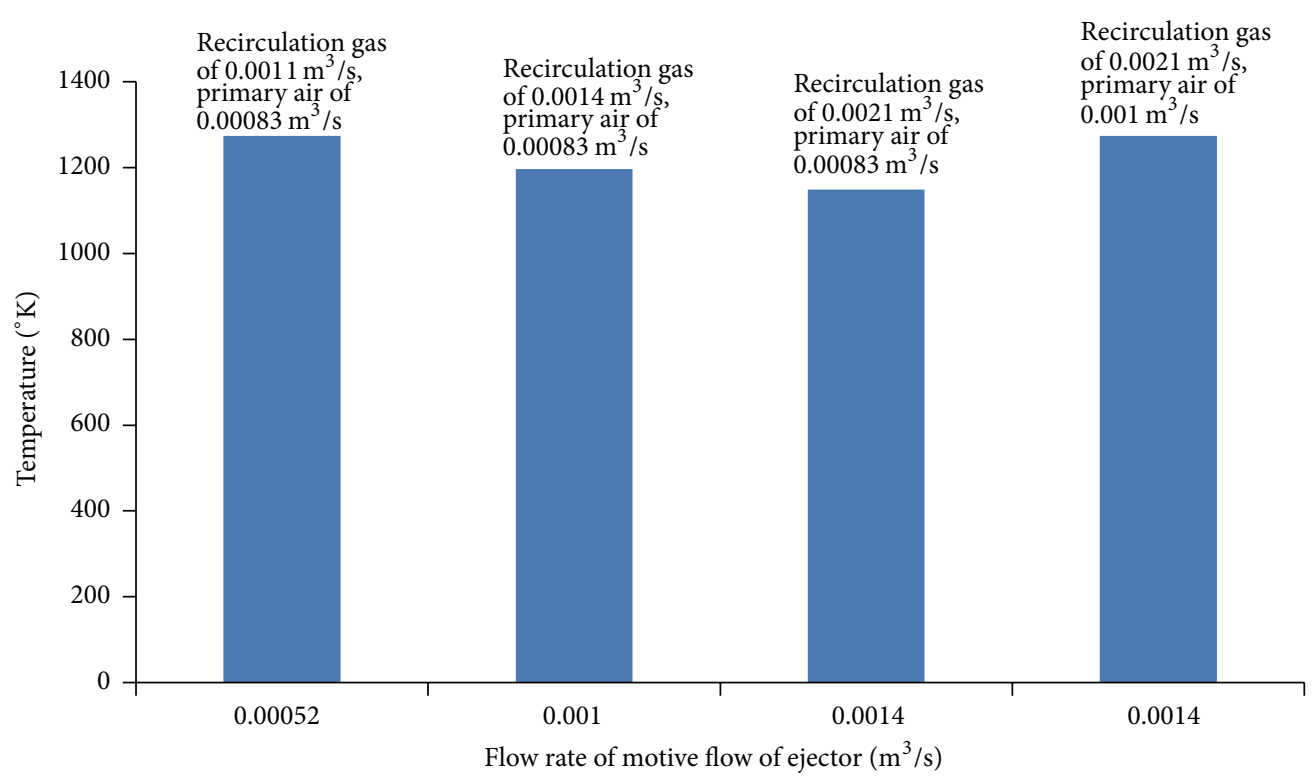

FIGURE 5: Combustion zone temperature versus motive flow ejector.

3.3. The Lower Heating Value of the Producer Gas. Figure 4 shows the effect of the flow of the pyrolysis gases in the combustion zone on the lower heating value of the gas.

When the pyrolysis gas recirculation rate was increased from $0.0011 \mathrm{~m}^{3} / \mathrm{s}$ to a maximum of $0.0021 \mathrm{~m}^{3} / \mathrm{s}$ at a constant primary air flow rate of $0.00083 \mathrm{~m}^{3} / \mathrm{s}$, the lower heating value of the gas increased from $4.3 \mathrm{MJ} / \mathrm{m}^{3}$ to $4.7 \mathrm{MJ} / \mathrm{m}^{3}$. This increase resulted from a significant increase in the concentration of $\mathrm{H}_{2}$ and a moderate decrease in the concentration of $\mathrm{CO}$. Furthermore, there was an increase in the concentration of $\mathrm{CH}_{4}$, which has a greater heating value than that of the other gases. When the primary air flow rate was increased to $0.001 \mathrm{~m}^{3} / \mathrm{s}$ and the pyrolysis gas recirculation rate was held constant at $0.0021 \mathrm{~m}^{3} / \mathrm{s}$, the lower heating value increased from $4.7 \mathrm{MJ} / \mathrm{m}^{3}$ to $4.9 \mathrm{MJ} / \mathrm{m}^{3}$ because of the significant increase in the concentration of $\mathrm{CO}$. 
3.4. Combustion Zone Temperature. Figure 5 shows the variation in the maximum temperature in the combustion zone with the ejector flow rate. When the pyrolysis gas recirculation was increased from $0.0011 \mathrm{~m}^{3} / \mathrm{s}$ to a maximum of $0.0021 \mathrm{~m}^{3} / \mathrm{s}$ at a constant primary air flow rate of $0.00083 \mathrm{~m}^{3} / \mathrm{s}$, the maximum temperature in the combustion zone decreased from $1273^{\circ} \mathrm{K}$ to $1148^{\circ} \mathrm{K}$ because the endothermic reaction that produces $\mathrm{H}_{2}$ (reactions (3)) became more dominant. The lower pyrolysis gas temperature led to a need for more heat to increase its temperature, causing a decrease in the temperature of the bed [17]. The temperature inside reactor was constant at over $1148^{\circ} \mathrm{K}$ so that the cracking and steam reforming of the tar were continuous.

When the primary air flow rate was increased to $0.001 \mathrm{~m}^{3} / \mathrm{s}$ and the pyrolysis gas recirculation was held constant at $0.0021 \mathrm{~m}^{3} / \mathrm{s}$, the temperature in the combustion zone increased from $1148^{\circ} \mathrm{K}$ to $1273^{\circ} \mathrm{K}$ because the increase in the flow rate of the primary air contributed to an increase in the exothermic combustion reaction (reaction (7)).

\section{Conclusions}

The recirculation of pyrolysis gases from the top of gasifier (drying zone) to the combustion zone and gas outlet from reduction zone in a modified updraft gasifier in this study resulted in maximum lower heating value of $4.9 \mathrm{MJ} / \mathrm{m}^{3}$. Increasing the flow of the pyrolysis gases to the combustion zone tended to reduce the amount of tar produced. The concentration of $\mathrm{H}_{2}$ tended to increase and the concentration of $\mathrm{CO}$ decreased with increasing motive flow rate and constant primary gasification air. Increasing flow rate of the primary gasification air tended to increase the amount of $\mathrm{CO}$ and decrease the amount of $\mathrm{H}_{2}$ produced.

\section{Conflict of Interests}

The authors declare that there is no conflict of interests regarding the publication of this paper.

\section{References}

[1] E. G. Pereiraa, J. N. da Silvaa, J. L. de Oliveirab, and C. S. Machadoa, "Sustainable energy: a review of gasification technologies," Renewable and Sustainable Energy Reviews, vol. 16, pp. 4753-4762, 2012.

[2] K. K. Gupta, A. Rehman, and R. M. Sarviya, "Bio-fuels for the gas turbine: a review," Renewable and Sustainable Energy Reviews, vol. 14, no. 9, pp. 2946-2955, 2010.

[3] A. K. Sharma, "Modeling and simulation of a downdraft biomass gasifier 1. Model development and validation," Energy Conversion and Management, vol. 52, no. 2, pp. 1386-1396, 2011.

[4] A. F. Kirkels and G. P. J. Verbong, "Biomass gasification: still promising? A 30-year global overview," Renewable and Sustainable Energy Reviews, vol. 15, no. 1, pp. 471-481, 2011.

[5] P. Stahlberg, M. Lappi, E. Kurkela, P. Simell, P. Oesch, and M. Nieminen, Sampling of Contaminants from Product Gases of Biomass Gasifiers, vol. 5 of VTT, Technical Research Centre of Finland Espoo, 1998.
[6] A. Surjosatyo, F. Vidian, and Y. S. Nugroho, "A review on gasifier modification for tar reduction in biomass gasification," An International Journal of Jurnal Mekanikal, no. 31, pp. 62-77, 2010.

[7] A. Surjosatyo, F. Vidian, and Y. S. Nugroho, "Performance gasification perbatch rubber wood in conventional updraft gasifier," Journal of Engineering and Applied Sciences, vol. 7, no. 8, pp. 494-500, 2012.

[8] P. Gilbert, C. Ryu, V. Sharifi, and J. Swithenbank, "Tar reduction in pyrolysis vapours from biomass over a hot char bed," Bioresource Technology, vol. 100, no. 23, pp. 6045-6051, 2009.

[9] J. P. A. -Neeft, H. A. M. Knoef, G. J. Buffinga et al., "Guideline for sampling and analysis of tar and particles in biomass producer gases," Energy Project ERK6-CT1999-20002 (Tar Protocol), 2002.

[10] C. Brage and K. Sjöström, An Outline of R\&D Work Supporting the Tar Guideline, Department of Chemical Engineering and Technology, Chemical Technology, Royal Institute of Technology (KTH), 2002.

[11] Y. Ueki, T. Torigoe, O. Hirofumi, Y. Ryo, J. H. Kihedu, and I. Naruse, "Gasification characteristics of woody biomass in the packed bed reactor," in Proceedings of the Combustion Institute, vol. 33, pp. 1795-1800, 2011.

[12] E. Kurkela, P. Ståhlberg, P. Simell, and J. Leppälahti, "Updraft gasification of peat and biomass," Biomass, vol. 19, no. 1-2, pp. 37-46, 1989.

[13] F. Vidian, A. Surjosatyo, and Y. S. Nugroho, "CFD analysis of external recirculation flow at updraft gasifier using ejector," in AIP Confrences Proceedings, vol. 1440, pp. 936-941, 2011.

[14] M. Seggiani, S. Vitolo, M. Puccini, and A. Bellini, "Cogasification of sewage sludge in an updraft gasifier," Fuel, vol. 93, pp. 486-491, 2012.

[15] T. Damartzis and A. Zabaniotou, "Thermochemical conversion of biomass to second generation biofuels through integrated process design-A review," Renewable and Sustainable Energy Reviews, vol. 15, no. 1, pp. 366-378, 2011.

[16] J. Šulc, J. Štojdl, M. Richter et al., "Biomass waste gasificationcan be the two stage process suitable for tar reduction and power generation?" Waste Management, vol. 32, no. 4, pp. 692-700, 2012.

[17] A. Kumar, D. D. Jones, and M. A. Hanna, "Thermochemical biomass gasification: a review of the current status of the technology," Energies, vol. 2, no. 3, pp. 556-581, 2009.

[18] A. Kaupp and J. R. Gross, "State of the art for small (2-50 kW) gas producer engine system," Final Report to USDA, Forest Service Contract No 53-39R-0-141, 1981.

[19] P. Donaj, M. R. Izadpanah, W. Yang, and W. Blasiak, "Effect of pressure drop due to grate-bed resistance on the performance of a downdraft gasifier," Energy and Fuels, vol. 25, no. 11, pp. 53665377, 2011.

[20] H. Kitzler, C. Pfeifer, and H. Hofbauer, "Pressurized gasification of woody biomass-Variation of parameter," Fuel Processing Technology, vol. 92, no. 5, pp. 908-914, 2011.

[21] L. E. Taba, M. F. Irfan, W. A. M. Wan Daud, and M. H. Chakrabarti, "The effect of temperature on various parameters in coal, biomass and CO-gasification: a review," Renewable and Sustainable Energy Reviews, vol. 16, pp. 5584-5596, 2012. 

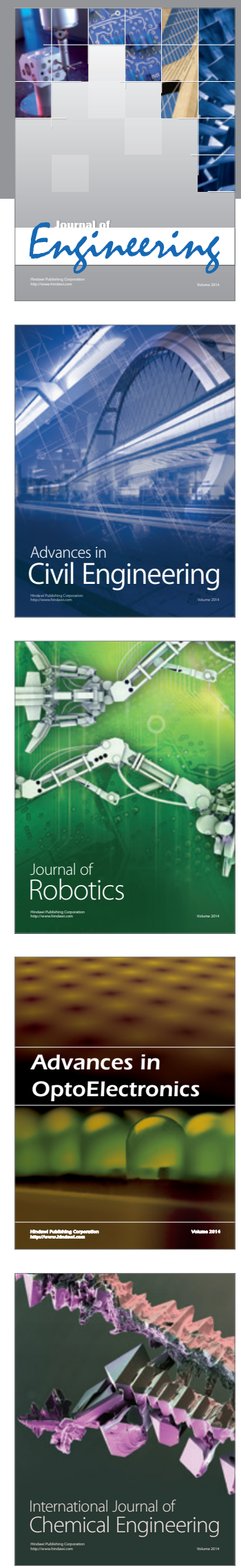

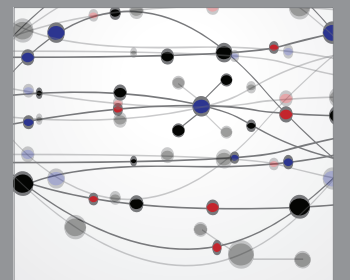

The Scientific World Journal
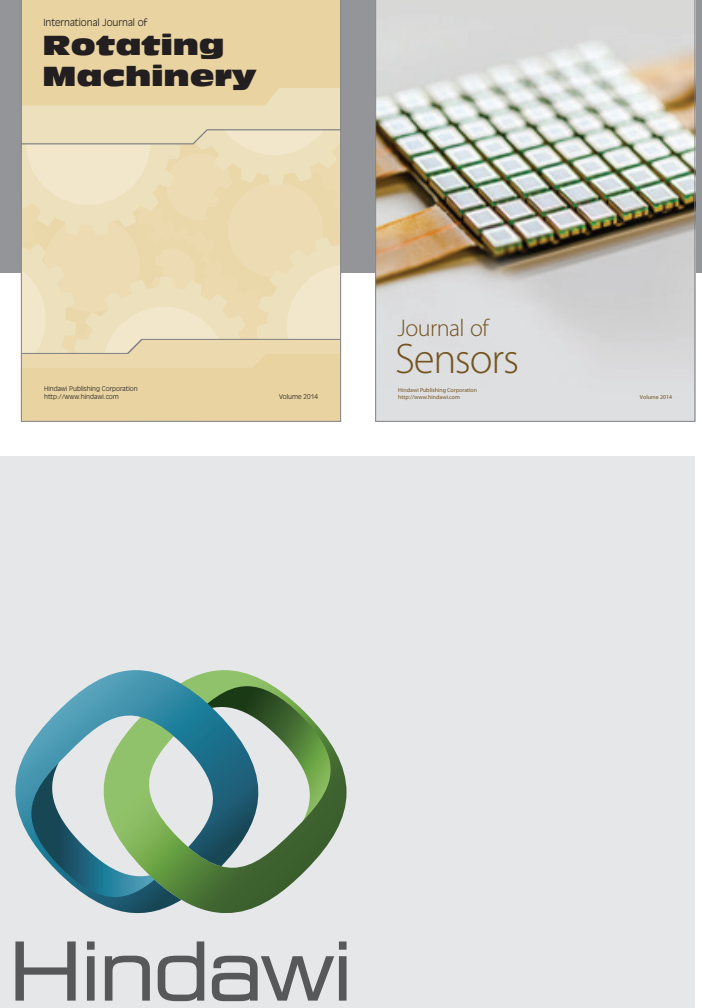

Submit your manuscripts at http://www.hindawi.com
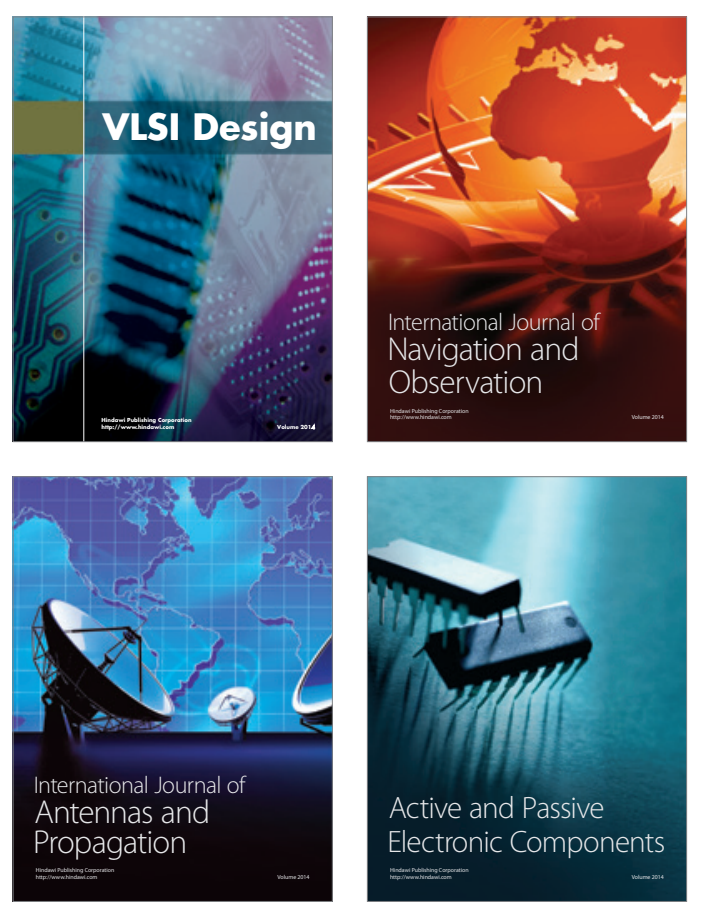
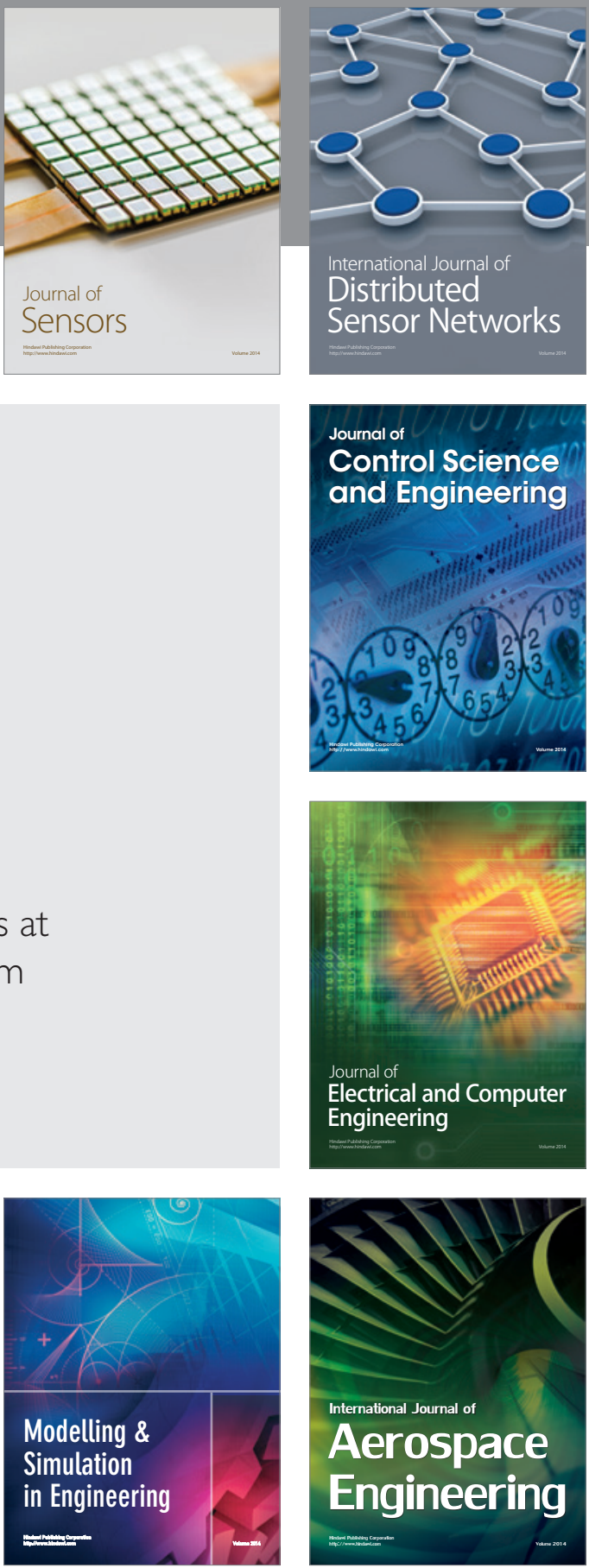

Journal of

Control Science

and Engineering
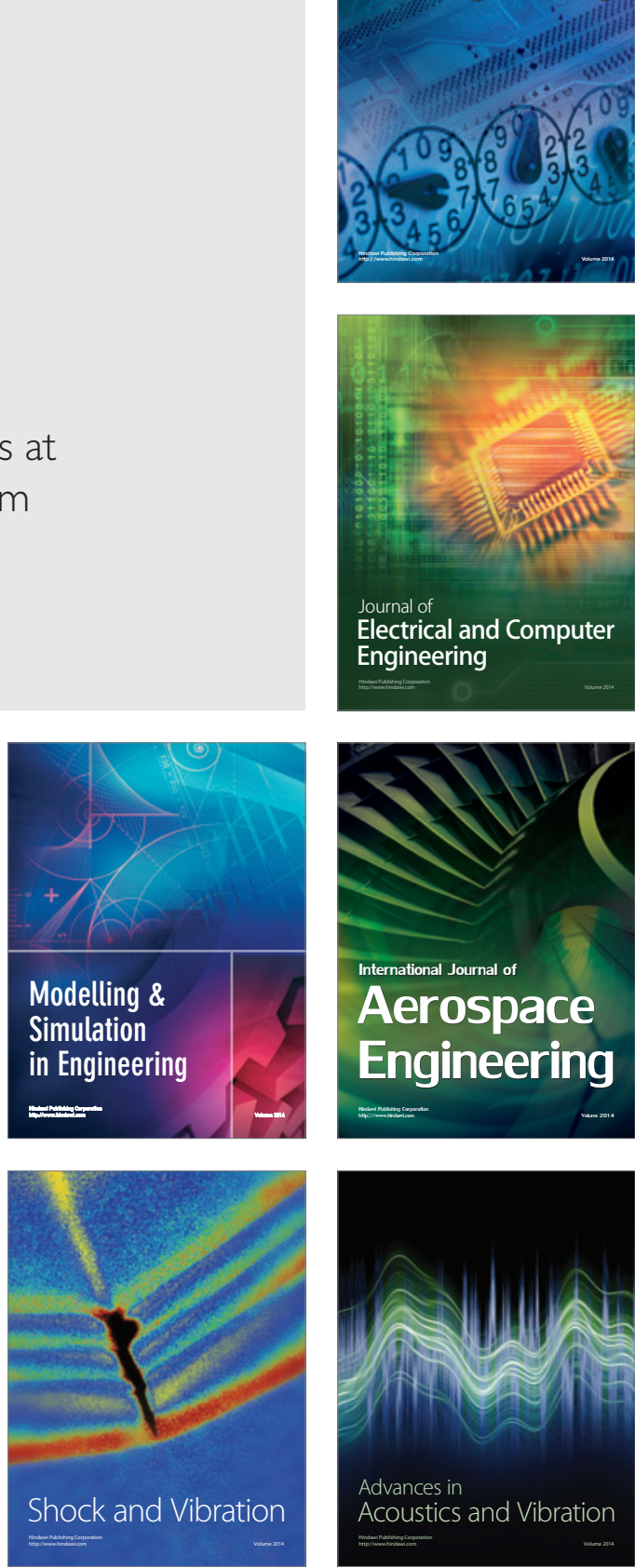